\title{
Charred olive stones: experimental and archaeological evidence for recognizing olive processing residues used as fuel
}

\author{
Freek Braadbaart ${ }^{1,2} \cdot$ Elena Marinova $^{3,4} \cdot$ Anaya Sarpaki $^{5}$
}

Received: 11 March 2015/Accepted: 15 February 2016/Published online: 26 February 2016

(c) The Author(s) 2016. This article is published with open access at Springerlink.com

\begin{abstract}
After extracting oil from olives a residue is left usually referred to as the olive oil processing residue (OPR). This study explores the way in which ancient societies may have used OPR as fuel for fires to generate heat and the various issues that are related to the residues of this fuel. After drying, the high heating value and structure of OPR makes it an excellent and efficient fuel. Upgrading OPR further, through thermal conversion or charring, provides an even more efficient fuel (COPR), with a hotter and smoke free flame, a higher heating value and which is lighter in mass and thus easier to transport. After a fire is extinguished two types of remains of the fuel are left i.e. char and ash. Analyses on both remains, recovered from archaeological deposits, could be used as a source of information on fuel utilization. Laboratory experiments on charred modern OPR and stones show that by measuring their reflectance and analyzing their structure under reflected light microscopy, OPR and COPR can be distinguished in the charred material recovered from three
\end{abstract}

Communicated by F. Bittmann.

Freek Braadbaart

brabra@wxs.nl

1 Faculty of Archaeology, Leiden University, PO Box 9500, 2300 RA Leiden, The Netherlands

2 Department of Earth Sciences-Geochemistry, Faculty of Geosciences, Utrecht University, P.O. Box 80021, 3058 TA Utrecht, The Netherlands

3 Centre for Archaeological Sciences, Katholieke Universiteit Leuven, Celestijnenlaan 200E, 3001 Leuven, Belgium

4 Royal Belgian Institute for Natural Sciences, Rue Vautier 29, 1000 Brussels, Belgium

5137 Tsikalarion Rd., Tsikalaria, Souda, 73200 Crete, Greece archaeological sites in Greece and Syria. Based on these investigations it is suggested that on the three sites COPR was used as fuel. Ash, sampled together with the char, provides the possibility of investigating if other types of fuel were used, apart from OPR or COPR. On the investigated sites no ash was collected, but the analysis of the modern OPR showed that the properties of its ash could be used to distinguish it from other types of fuel. Ash from modern OPR and olive stones showed the presence of phytoliths. The often discussed issue related to the sharpness and smoothness of the edges of charred fragmented olive stones was investigated. The results showed that this is not a reliable criterion for recognizing olive oil production. It is recommended that in addition to the identification of the botanical material more properties of the remains of fuels should be analysed. To prevent destroying and losing char and ash as a result of excavation activities such as flotation and sieving, special measures have to be taken. The results show that analysing char and ash may provide valuable information on the (pyro)technology practised in ancient societies.

Keywords Olive stones - Olive processing residue . Charring $\cdot$ Fuel $\cdot$ Reflectance $\cdot$ Archaeobotany $\cdot$ PorosAkrotiri-Tell Tweini

\section{Introduction}

The olive tree, Olea europaea L., characterizes the modern landscape of the Mediterranean region to a great extent, since this is the principal area for olive cultivation in the old world. Its fruits, i.e. the olives, have been used as a direct food source, but their main use has been as a source of oil for consumption and other uses. To extract the oil, 
olives need to be crushed and pressed and the resulting oil has to be separated from the olive pressing residue (OPR). The principle of extracting oil from the fruits has since ancient times not changed fundamentally, although technical details may have changed (Tyree and Stefanoudaki 1997; Warnock 2007). The organic composition of OPR makes it in principle a material to be used as fuel. Yet, instead of using the OPR directly as fuel it can be upgraded, by drying, to remove most of the water or by further thermal conversion into fuels with a higher heating capacity. The latter application will produce charred OPR (COPR), a fuel considerably less in weight and which burns with a hotter flame, using less material and which is almost smoke free compared to OPR. After being ignited, these types of fuel will provide fire, which in turn will generate the wanted heat. When the fire is extinguished, its remains are normally char and ash. Both remains provide the only indication of the original type of fuel and impart an insight into the variety of fuels utilized in the past.

To initiate a fire an interaction has to take place between a fuel, air and heat from an external heat source-the three basic elements of the fire triangle (Emmons and Atreya 1982). A fuel is composed of water, an inorganic ash fraction and an organic fraction, the latter providing the potential energy that can be transformed into the required heat energy. Once a heat source has been introduced to the fuel, heat is absorbed and the heated fuel begins to increase in temperature. When a temperature of $280-300{ }^{\circ} \mathrm{C}$ is reached, a complex chemical reaction starts that leads to the thermal degradation of the organic constituents of the fuel, producing volatile gases and a charred residue (Rein 2009; Braadbaart et al. 2012). Only then, and with enough air, will both products oxidize, which is a highly exothermic process, meaning that heat will be generated and released. As long as the temperature remains above $300{ }^{\circ} \mathrm{C}$ and with enough air the volatile gases will produce the flames and the carbon rich char will be converted into carbon dioxide $\left(\mathrm{CO}_{2}\right)$, both reactions releasing heat. The residue of the latter is the inorganic ash. But when temperature decreases and not enough air is made available, the fire will be extinguished. Under these conditions not only ash, but also the char provide the indications of the original type of fuel and possibly the heating conditions of the fire, which in turn may give an indication of the purpose of the fire. Ash, as well as char, is frequently recovered from archaeological contexts (Bakels 1984). Fuel may originate from several resources such as modern vegetation, fossil fuel, agricultural residues, dung etc. Studies of its organic and inorganic residues, both visible and invisible to the naked eye, help illustrate this potential source of data preserved within archaeological contexts. These data can help further understanding of past human behaviour not only in terms of fuel selection, but also the basis on which a society may have selected a particular fuel type, as well as providing information pertaining to the relative level of generation, control and application of heat (pyro)technology) used in past societies. This is important as the degree of (pyro)technology afforded by one society over another is taken as a measure of the level or quality of civilization of that society (Goudsblom 1992; Mumford 1963).

Earlier studies have assessed the physical and chemical changes, as a result of heating, of the properties of fruits and seeds like wheat grains, pea seeds and sunflower achenes and seeds (Braadbaart 2004; Braadbaart et al. 2007). The results show that the chemical changes, which are characterized by the conversion of the fuel's constituent biomolecules into a material consisting of aromatic compounds, are also valid for the material discussed in this paper. The current study describes the changes, as a result of heating, of the physical and chemical properties of the agricultural residue of the fruits of olive trees, a fuel often used in modern days as well as in the past (Demirbaş and Ilten 2004).

This study explores the way in which ancient societies may have used the OPRs as fuel and the various issues that are related to the remains of this type of fuel after their having been subjected to the natural processes to which they were exposed after being deposited in the soil, and the subsequent excavation and interpretation activities of the archaeologist. To address these matters the following questions were dealt with: (i) What are the fuel characteristics of OPR and COPR? (ii) At what temperature were the residues heated and which was their relevance as fuel in the past? (iii) Does the morphology of the edges of the crushed charred olive stones say anything about their use? (iv) Could the analysis of ash from fireplaces add further information on the nature and use of those residues?

To answer these questions experiments were performed in the laboratory on the stones of modern olives as well as archaeological stones and on modern OPR. The results of these experiments were assessed and used to investigate the charred olive stones fragments from the Early and Middle Bronze Age site of Akrotiri on the island of Thera in Greece, the Middle Bronze Age site of Tell Tweini in Syria and from the excavation of the sanctuary site of the Temple of Poseidon at Kalaureia (olives mainly from Hellenistic strata) on the island of Poros in Greece.

\section{Properties of olive stones and pressing residue related to their use as fuel}

\section{Anatomy}

For a detailed description of the morphology and anatomy of olive fruits, the reader is referred to the work of 
Vaughan (1970) and Winton and Winton (1932). In brief, technically the olive fruit is a drupe and can be separated into four anatomical parts: epicarp, mesocarp, endocarp and kernel (seed) (Fig. 1a). The epicarp (skin, peel, epidermis) is covered with wax. The mesocarp (pulp, flesh) is the major part of the tissue as it contains $60-85 \%$ of the total dry weight of the whole fruit (Fig. 1a) and has low sugar and high oil content that varies according to the variety and the ripeness of the fruit (Niaounakis and Halvadakis 2006). It is of economic importance for table consumption as well as for oil production. Its main chemical components are water (50-60\%) and oil (15-30 \%) (Table 1). The endocarp (stone, pit) is hard and made of fibrous lignin and encloses the olive kernel (seed).

In various plant tissues amorphous silica (in the form of opal) deposits usually referred to as phytoliths can occur (Piperno 2006; Madella et al. 2005). Calcium oxalate crystals can occur in all plant tissues (Franceschi and Nakata 2005; Canti 2003). In olives silica phytoliths and calcium oxalate crystals are also recognized, although in the literature no information was found on olives (Tyree 1994; Pearsall 2000, p. 358). Since at least the phytoliths have the property of surviving the destructive processes that may occur after being deposited in the soil they are often used in palaeo-environmental and archaeo-botanical research; thus an effort has to be made to investigate whether these features may occur in olive fruits.

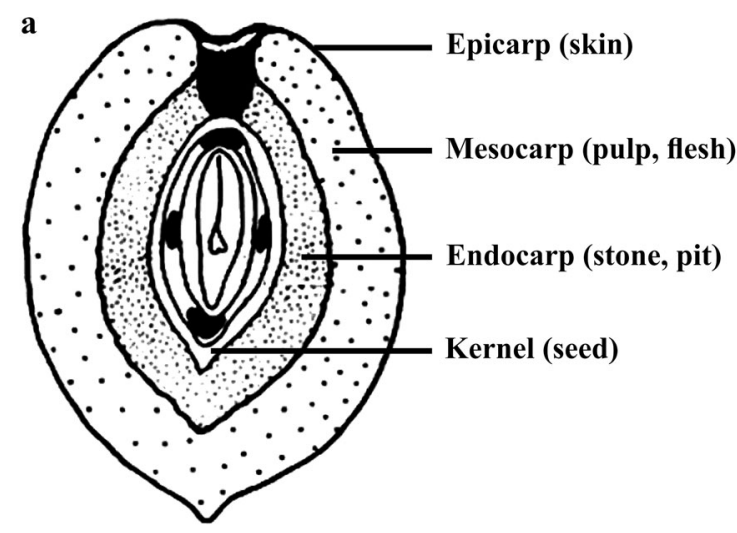

b

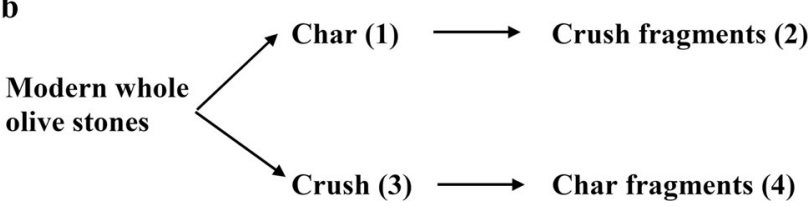

Fig. 1 a Cross section of olive fruit; b scheme showing how fragments of modern olive stones were prepared and charred
Table 1 A representative chemical composition of olive fruit (\%)

\begin{tabular}{llll}
\hline Component & Pulp & Stone & Seed \\
\hline Water & $50-60$ & 9.3 & 30 \\
Oil & $15-30$ & 0.7 & 27.3 \\
N cont. compounds & $2-3$ & 10.2 & 3.4 \\
Sugar & $3-7.5$ & 41 & 26.6 \\
Cellulose & $3-6$ & 38 & $3-6$ \\
Minerals & $1-2$ & 4.1 & 1.5 \\
Polyphenols & $2.25-3$ & 0.1 & $0.5-1$ \\
Other compounds & - & 3.4 & 2.4 \\
\hline
\end{tabular}

Adapted from Niaounakis and Halvadakis (2006)

\section{Fuel characteristics of olive pressing residues}

The oil is produced in the mesocarp cells of the fruit. To extract the oil, the fruits have to be crushed and pressed in order to bruise the fleshy cells and facilitate the release of oil from the oil-vacuoles. Morphology of the parts of the OPR and other details like ratio of fragments to whole stones, size of fragments, the presence of oil etc. are discussed in the work of Warnock (2007). After the extraction the OPR is also known under various other names such as crude olive cake, jift or pomace, among others. The various fuel properties of OPR and other biological fuels, as found in the literature, are summarized in Table 2. The total amount of heat available per unit mass $(\mathrm{kg})$ of a fuel can be referred to as the high heating value (HHV) or gross calorific value (GCV), both expressed in $\mathrm{J} \mathrm{kg}^{-1}$. The HHV for most biological fuel types is of the order of $20 \mathrm{MJ} \mathrm{kg}^{-1}$ and this is also valid for OPR (references see Table 2). It is noted that water and the inorganic ash fraction can significantly decrease the HHV of a fuel. A water content of $50 \%$ in, for example, fresh wood will reduce the HHV to around $8 \mathrm{MJ} \mathrm{kg}^{-1}$. Simple air drying to around $15 \%$ by weight water is a very effective means to significantly improve its heating potential to about $17 \mathrm{MJ} \mathrm{kg}^{-1}$ (Braadbaart et al. 2012). The ash content of both olive stones and OPR is of the order of $1 \%$ and therefore the effect on the heating potential is negligible. The carbon content of the OPR as well as the stones is about $52 \%$ by weight or higher than other types of biomass such as wood (Table 2), which may be explained by the high lignin content in olive stones (Demirbaş and Ilten 2004). Due to this relatively high carbon content, the presence of an element like potassium (Di Blasi 2009) and the presence of some oil, the OPR can be qualified as an excellent fuel (Table 2). A factor that may also influence the generation of heat from a fuel is its structure and thus the ease by which air (oxygen) passes through the layer of combusting fuel. The structure of OPR can be compared with the 
Table 2 Ultimate, proximate and chemical analyses of olive stone and olive residue

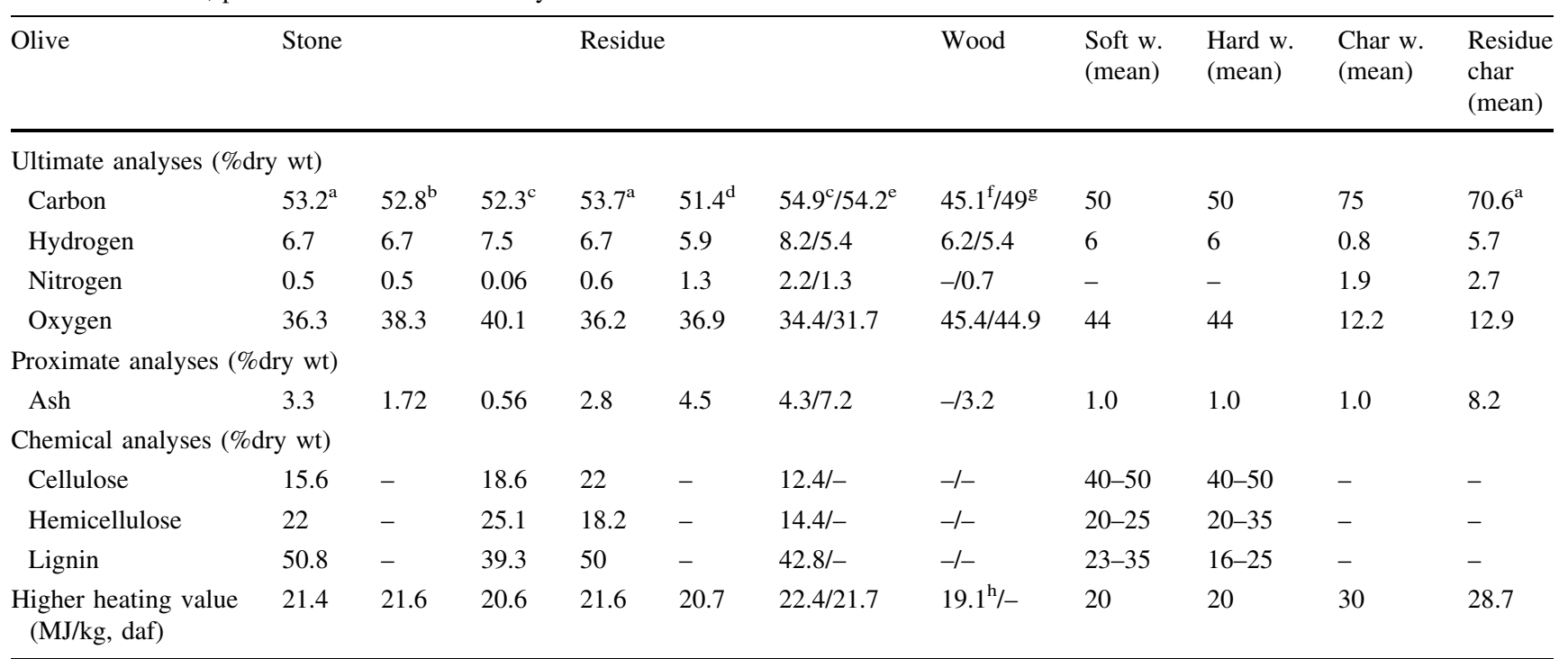

For comparison results of olive, hard and soft wood and chars of wood and olive residue are given

a Demirbaş and Ilten (2004)

b Jenkins et al. (1998)

c Miranda et al. (2008)

d Varol (2006)

e Tortosa Masiá et al. (2007)

${ }^{\mathrm{f}}$ Grioui et al. (2007)

g Vassilev et al. (2010)

h Vamvuka (2008)

structure of fuels like peat and dung. It was shown that these fuels, with their compact fibre structure, have a lower rate of combustion relative to wood with its relatively open structure. This renders the former fuels more efficient since they require less fuel for an equivalent heat yield than wood, as extensively explained in Braadbaart et al. (2012).

Apart from simple air drying the HHV of the OPR can be further upgraded by thermal degradation, a process also used to convert wood into charcoal, whereby the carbon content is substantially increased from around $50-70 \%$ by weight or higher (Table 2). Accordingly, the HHV of wood increases by $50 \%$ to $30 \mathrm{MJ} \mathrm{kg}^{-1}$. Experiments by Demirbaş and Ilten (2004) have shown that this is also valid for OPR, which increased the HHV to $28.7 \mathrm{MJ} \mathrm{kg}^{-1}$ (Table 2). This means that in the case of OPR two types of fuel can be distinguished: (1) after air drying OPR can be used directly as a fuel and (2) OPR is thermally degraded by heating, in the absence or near absence of air, in the range of $450-500{ }^{\circ} \mathrm{C}$. Through thermal degradation the OPR is transformed into a more efficient type of fuel with a higher HHV and is referred to as COPR. In the latter case the weight (mass) of the fuel is also reduced, which facilitates transportation. Moreover, a hotter and smoke free fire which uses less fuel is obtained.

\section{Materials}

\section{Modern material}

Modern olive stones were obtained in 2010 from a tree situated on the archaeological site at Kalaureia on the island of Poros situated about $500 \mathrm{~m}$ from the Peloponnesian coast, in Greece (Penttinen and Wells 2009). Since most of the stones found in archaeological sites discussed in this study are fragmented, the modern stones were fragmented by crushing before and after heating them. The stones were used to prepare a calibration curve for reflectance measurements. In addition fresh olives from cultivars for oil production were harvested by hand from Syrian (2009) and Italian (2008) groves; these are the same as used by Marinova et al. (2011) for experiments in order to observe the edges of breakage. A modern olive residue was prepared using a Roman mill at the Israel Olive Oil 
Museum in Haifa, Israel. The residue was described and kindly donated by Peter Warnock (Warnock 2007). The modern OPR was heated in the presence of air and the resulting ash chemically analysed. The stones in this residue were all fragmented.

\section{Archaeological material}

Information about the various samples is summarized in Table 3. The stones present in these samples were all fragmented.

The Kalaureia Research Programme on Poros investigates the relationship of the ancient buildings to the Sanctuary of Poseidon (Penttinen and Wells 2009). From this site organic remains have been recovered from the sediments by water flotation and 5 samples of charred fragmented olive stones were made available i.e. WF112R, WF115, WF118R, WF114R and WF273R. Samples are dated from the Archaic to the Roman period.

The Minoan eruption of the island of Thera (cal 1600 BCE) discharged tephra, magma and ash over a wide area of

Table 3 Results reflectance measurements (\%Ro)

\begin{tabular}{lllll}
\hline Site $\quad$ Sample nr. & $\mathrm{N}$ & $\%$ Ro & $\mathrm{SD}$ & Temp $\left({ }^{\circ} \mathrm{C}\right)$ \\
\hline Modern stones & & & & \\
$310{ }^{\circ} \mathrm{C}$ & 100 & 0.2 & 0.058 & 310 \\
$340{ }^{\circ} \mathrm{C}$ & 100 & 0.426 & 0.060 & 340 \\
$400{ }^{\circ} \mathrm{C}$ & 100 & 1.056 & 0.102 & 400 \\
$500{ }^{\circ} \mathrm{C}$ & 100 & 1.681 & 0.088 & 500 \\
$600{ }^{\circ} \mathrm{C}$ & 100 & 2.903 & 0.129 & 600 \\
$700{ }^{\circ} \mathrm{C}$ & 100 & 4.796 & 0.532 & 700 \\
Poros & & & & \\
WF112R & 100 & 1.678 & 0.161 & 500 \\
WF115 & 100 & 1.515 & 0.141 & 490 \\
WF118R & 100 & 1.473 & 0.137 & 490 \\
WF114R & 100 & 1.574 & 0.244 & 490 \\
WF273R & 100 & 1.503 & 0.169 & 490 \\
Akrotiri & & & & \\
OS 64-178 & 136 & 0.983 & 0.169 & 390 \\
OS 64-667 & 109 & 0.937 & 0.076 & 390 \\
OS 64-806 & 80 & 1.366 & 0.090 & 470 \\
OS 64-1183 & 100 & 1.481 & 0.112 & 490 \\
OS 61-580 & 100 & 0.919 & 0.124 & 390 \\
OS 61-745 & 100 & 1.093 & 0.104 & 390 \\
Tell Tweini & & & & \\
TWE05185 & 100 & 1.602 & 0.185 & 500 \\
TWE05942 & 100 & 1.603 & 0.156 & 500 \\
TWE06959 & 100 & 1.316 & 0.118 & 470 \\
\hline & & & \\
\hline
\end{tabular}

The modern stones are heated under reducing conditions for $60 \mathrm{~min}$ at the given temperature. Temperature of the archaeological stones was determined using the calibration graph as presented in Fig. 3

$N$ number of measurements, $S D$ standard deviation the island and buried the Late Bronze Age settlement of Akrotiri (Doumas 1983). Six samples of charred fragmented olive stones were chosen from the water flotation samples from this site. The samples were deliberately chosen below the final phase of habitation and therefore had not been affected by the heat from the eruption and are dated to the Early Cycladic (EC) and Middle Cycladic (MC) periods (cal 2600-1700 BCE) (Sarpaki and Asouti 2008; Sarpaki in press). From new trench (NT) 64 the charred samples numbered 178, 667, 806 and 1,183 and from trench NT 61 the charred samples 580 and 745 were used. Samples 178, 745 and 1,183 are dated to EC, samples 667 and 806 to the MC, whereas sample 580 is of mixed dates EC/MC.

The site of Tell Tweini on the Syrian coast, ancient Gibala (Bretschneider and van Lerberghe 2008), was almost continuously occupied from the Early Bronze Age to the Iron Age, and has been studied archaeobotanically. It produced numerous charred fragments of olive stones from flotation samples (Marinova et al. 2012). For the current study, olive stone fragments from the Middle Bronze Age (cal 2000-1600 BCE) were selected from three samples i.e. TWE-2005-locus 05185, TWE-2005-locus 942 and TWE2006-locus 959.

From the three investigated sites charred flesh and other tissues, such as kernels, were occasionally found and attributed to olive or generally fruit, but not further analysed. Ash was not systematically noted and analysed.

\section{Methods}

Figure $1 \mathrm{~b}$ gives an overview of the preparation of the samples of modern olive stones used in the laboratory experiments performed in this study. (1) Whole fresh stones were charred at a range of temperatures and (2) part of these charred stones was crushed into fragments. (3) Whole fresh stones were crushed and (4) part of the resulting fragments were charred.

\section{Modern olive stones}

The modern olives were defleshed by hand and the stones fragmented with an agate pestle and mortar. In this way the stones are comparable with fragmented stones frequently recovered from archaeological sites and also used for this study.

\section{Experimental heating of whole and crushed olive stones}

The procedure of Braadbaart (2004) was adopted in order to experimentally char (carbonize) whole and crushed fresh olive stones. For this purpose from each sample five specimens were heated in a Carbolite tube oven (model MTF 
$12 / 38 / 250$ ) at atmospheric pressure under a constant flow of nitrogen $\left(150 \mathrm{ml} \mathrm{min}^{-1}\right)$ to ensure anoxic or reducing conditions. The specimens were placed in an open Pyrex ${ }^{\circledR}$ vessel and inserted into a $30 \mathrm{~cm}$ long Pyrex ${ }^{\odot}$ tube $(\varnothing$ $2.3 \mathrm{~cm}$ ) at $18 \mathrm{~cm}$ from the inlet, which in turn was inserted into the pre-heated oven. To prepare the calibration curve for olive stones and based on previous experiments (Braadbaart and Poole 2008) the whole stones were heated for $60 \mathrm{~min}$ at each of the following temperatures: 310, 370, 400, 500, 600 and $700{ }^{\circ} \mathrm{C}$ (1 in Fig. 1b). Mass loss was calculated by weighing the samples before and after heating. Resultant gases and volatiles were vented and not investigated further. The same procedure was carried out for the fragments of the crushed fresh olive stones and based on the results of the whole fresh stones, as presented in the calibration curve (Fig. 2), it was decided that charring the fragments at $310,370,400$ and $500{ }^{\circ} \mathrm{C}$ for 60 min gave a sufficient representative result ( 4 in Fig. 1b). In addition modern stones were ashed by heating them for $60 \mathrm{~min}$, under air flow (ashed) at $450{ }^{\circ} \mathrm{C}$, in a muffle furnace.

\section{Physical analyses}

The reflectance $\left(\% \mathrm{R}_{\mathrm{o}}\right)$ measured on charred organic material provides information regarding the temperature at which the material was heated. Reflectance is defined as the percentage of vertically incident monochromatic light reflected from a highly polished surface of a sample

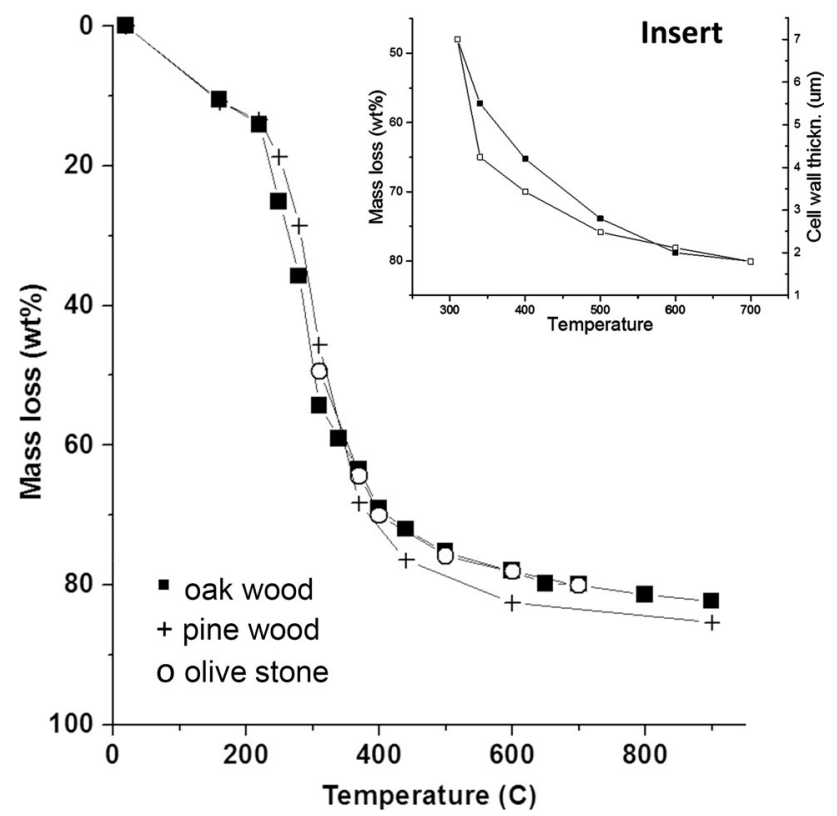

Fig. 2 Mass loss (wt\%) of modern olive stones (open circles), oak (solid squares) and pine (crosses) experimentally heated under reducing conditions for $60 \mathrm{~min}$ plotted as a function of the temperature $\left({ }^{\circ} \mathrm{C}\right)$. Insert showing mass loss of olive stones (open circles) in relation to cell wall thickness (solid squares) related to temperature $\left({ }^{\circ} \mathrm{C}\right)$ calibrated against the light reflected from a standard of known reflectance. To determine relative reflectance and any taxonomic differences, the three planes of the section (transverse, radial- and tangential-longitudinal) for three specimens were studied using experimentally produced charred whole olive stones at the mentioned final temperatures between 310 and $700{ }^{\circ} \mathrm{C}$. A Leitz motorized DMLA microscope equipped with a xyz-stage and a Basler camera was used. For a detailed description of the method the reader is referred to Braadbaart (2004).

\section{Anatomical analyses}

The anatomical structure of the modern whole fresh stone sample and various charred stone samples, embedded in resin and polished, were examined by observing the endocarp in cross-section using the Leitz microscope as described above. SEM microscopy (see e.g. Marinova et al. 2011) was also used and compared to the observations on polished sections. The anatomy of the breakage surfaces of the fragments of crushed whilst charred ( 2 in Fig. 1b) and crushed but uncharred ( 3 in Fig. 1b) stones as well as the charred fragments of the latter (4 in Fig. 1b) were studied by incident light using a binocular and reflected light Zeiss Axioscope microscope. The cross section view of the surfaces of the fragments of all the crushed stones was chosen for comparability. In this way special attention was given to the difference between the shape of the breakage surfaces before and after crushing.

\section{Modern olive oil pressing residue}

Preparation of ash and the phytolith study

The modern OPR was heated under air flow (ashed) at $450{ }^{\circ} \mathrm{C}$ for $60 \mathrm{~min}$ in a muffle furnace to complete the oxidation (Antal and Grönli 2003), using batches in three separate crucibles. For the phytolith study $4 \mathrm{mg}$ of ash was thoroughly mixed with $2 \mathrm{ml}$ Millipore water. Using a pipette, $0.05 \mathrm{ml}$ of each mixture was mounted on a glass slide. In this way, each slide contained an equal amount of ash i.e. $0.1 \mathrm{mg}$. These slides were examined for phytoliths using trans-illumination under a Leica DM 6000 M microscope.

\section{Elemental analyses on ash samples}

For the elemental analyses, the ashed OPR was used without any further chemical treatment. The ash residue was measured using the HH XRF Thermo Scientific Niton XL3t device with GOLDD detector equipped with a silver anode operating at a maximum of $50 \mathrm{kV}$ and $40 \mu \mathrm{A}$. This device is well suited for the measurement of up to 25 elements simultaneously in the analytical range between $\mathrm{S}$ 
(16) and U (92). Light elements ( $\mathrm{Mg}, \mathrm{Al}, \mathrm{Si}$ and P) can also be measured with the same detector using a He purge. The samples were measured in bulk mode. The device was factory calibrated and further elemental standards were also measured.

\section{Charring}

Samples of modern OPR were charred at 340 and $450{ }^{\circ} \mathrm{C}$ for $60 \mathrm{~min}$ to observe the influence of the oil still present on the charring results. These temperatures were selected because at the lower temperature oil will still be present and at the higher temperature the oil will be evaporated (Braadbaart et al. 2007). Charring was performed in the tube oven as described above. The mass loss was calculated and the resulting material described.

\section{Archaeological samples}

\section{Physical analyses}

The reflectance of each sample of charred fragmented stone was determined as described above for the modern samples. Based on these results, information was obtained about the temperature at which the samples had been charred in the past.

\section{Morphological analyses}

The anatomical features of the cross section of fruit stones from archaeological samples were observed by two methods. Firstly, the samples embedded in resin and polished as used for the determination of the reflectance, were examined under reflected light and oil immersion using the Leitz motorized DMLA microscope. Secondly, the samples were studied by binocular and reflected light microscopy using a Zeiss Axioscope microscope, giving special attention to cell morphology, cell wall thickness and possible alternations due to charring.

\section{Results}

\section{Modern olive stones}

\section{Mass loss as result of charring}

Modern olive stones were charred at 310, 340, 400, 500, 600 and $700{ }^{\circ} \mathrm{C}$ for periods of $60 \mathrm{~min}$. For each temperature a separate experiment was carried out. The respective mass losses were 43.43, 64.42, 70.01, 75.86, 78.11 and 80.11 wt\% (Fig. 2). Mass losses are presented, for comparative purposes, together with those of charred oak and pine wood (Fig. 2). A strong mass loss is observed in the range of $280-370{ }^{\circ} \mathrm{C}$, after which the mass loss decreases slowly. The fragments of the crushed fresh stones were charred for $60 \mathrm{~min}$ at $310,370,400$ and $500{ }^{\circ} \mathrm{C}$. The mass losses were 43.94, 65.32, 69.03 and $75.66 \mathrm{wt} \%$, respectively (4 in Fig. 1b), which is in accordance with the mass losses obtained by charring whole stones (Fig. 2).

\section{Reflectance measurements on charred whole stones}

The mean reflectance values (\%Ro) measured on the charred modern olive stones range from 0.2 at $310^{\circ} \mathrm{C}$ to 4.8 at $700{ }^{\circ} \mathrm{C}$ (Table 3; Fig. 3). These values correspond to reflectance values determined for charred organic material like angiosperm wood (Quercus, Fagus) and gymnosperm wood (Pinus, Taxus) and various fruits and seeds (Fig. 3) (Braadbaart and Poole 2008).

\section{Cell walls observed in resin embedded charred whole stones}

The sample of olive stone charred at $310{ }^{\circ} \mathrm{C}$ showed the characteristic elongated cells with cell walls that had a thickness of about $7 \mu \mathrm{m}$ (Fig. 4a). At $370{ }^{\circ} \mathrm{C}$ the cells could still be recognized whereby the thickness of the walls decreased to about 5-6 $\mu \mathrm{m}$ (Fig. 4b). When charred at $400{ }^{\circ} \mathrm{C}$ (Fig. 4c) the cells are still recognizable, but not

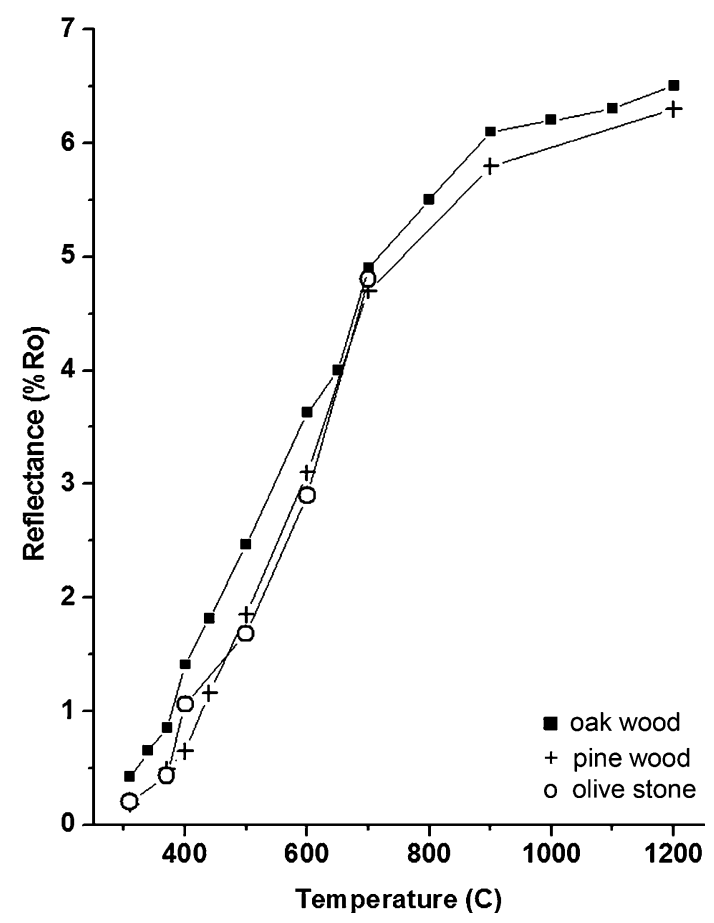

Fig. 3 Mean reflectance measurements (\%Ro) taken from olive stones (open circles) compared to oak (solid squares) and pine wood (crosses) samples experimentally heated under reducing conditions, plotted as a function of the final temperature $\left({ }^{\circ} \mathrm{C}\right)$ 
clearly distinct anymore. The cell wall thickness shows further shrinkage to about $4 \mu \mathrm{m}$. In addition, at this temperature, charred material without cell structure is observed. Under SEM microscopy, for this range of temperatures, similar changes are visible in experimentally charred and subsequently crushed olive stones compared with the specimens embedded in resin and polished (Fig. 5). At $500{ }^{\circ} \mathrm{C}$ the cells are hardly recognizable (Fig. 4d). The walls of the few recognizable cells are now only about $3 \mu \mathrm{m}$ thick. Here again, the cell wall material from numerous cells seemed to have been transformed into a homogeneous mass showing no cells and clearly different from the characteristic cell structure as observed at lower temperatures. The amount of charred cell material present in the picture is further decreased and this development continues when the temperature is raised to $600{ }^{\circ} \mathrm{C}$ (Fig. 4e). Now smaller cells and relatively more material without cell structure are observed, and cell wall thickness
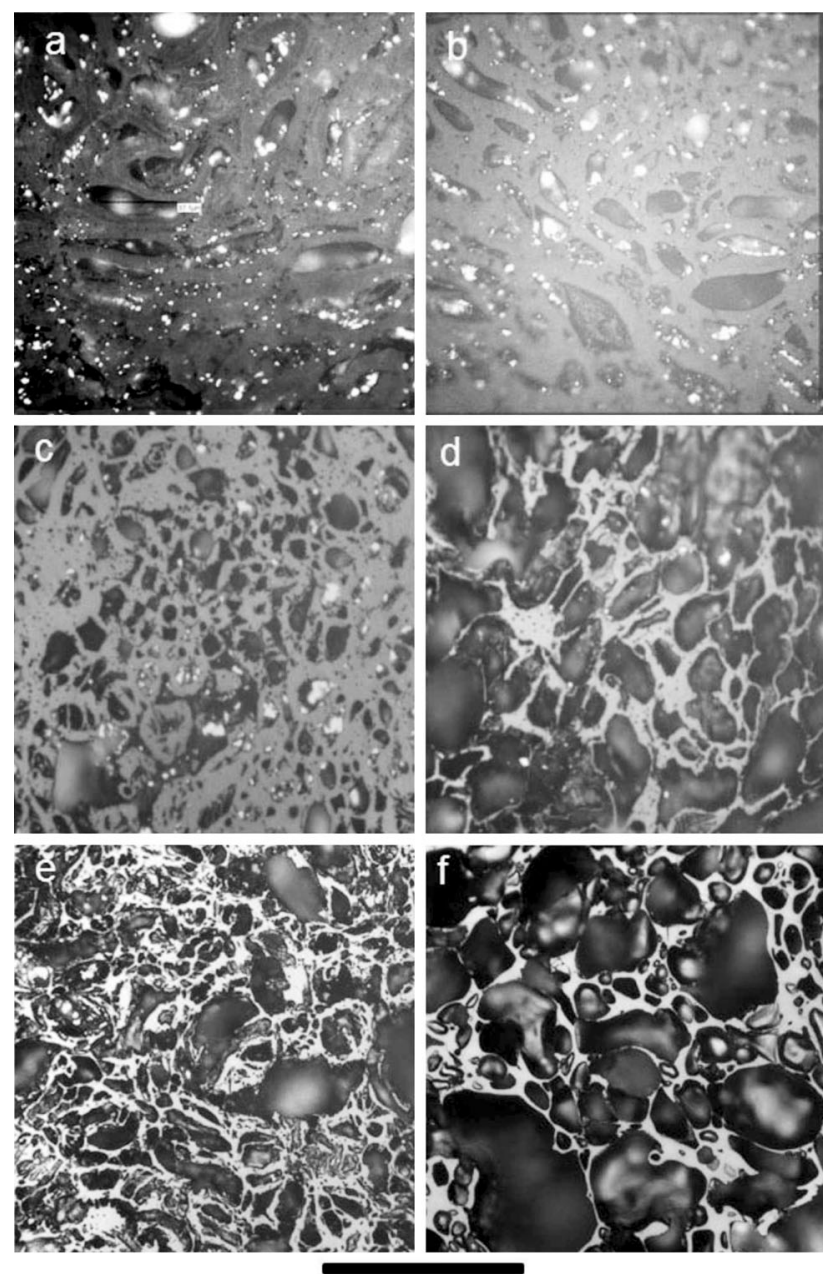

Fig. 4 Micrographs under reflected light of charred olive stones heated under reducing conditions. Heated at the temperatures: a $310{ }^{\circ} \mathrm{C}$, b $370{ }^{\circ} \mathrm{C}$, c $400{ }^{\circ} \mathrm{C}$, d $500{ }^{\circ} \mathrm{C}$, e $600{ }^{\circ} \mathrm{C}$ and f $700{ }^{\circ} \mathrm{C}$. Scale bar $100 \mu \mathrm{m}$ reduces further to about $2 \mu \mathrm{m}$. There is less material present in the picture, a feature that is also very clear when the stones are charred at $700{ }^{\circ} \mathrm{C}$, with cell walls about $1.5 \mu \mathrm{m}$ thick (Fig. 4f). The decrease of the cell wall thickness in relation to the charring temperature corresponds well to the mass loss of the stones (Fig. 2, insert).

\section{Breakage surfaces}

The fragments of fresh (not charred) olive stones showed edges that were rather sharp, but also edges that could be described as rounded along the fractures (Fig. 6a1). The examples given in Figs. 6a2, 3 (4 in Fig. 1b), show identical features. The fragments from stones charred and crushed afterwards ( 2 in Fig. 1b) show very sharp edges as well as edges that are rather rounded along the fractures (Figs. 6b1-3).

\section{Modern olive pressing residue (OPR)}

\section{Structure}

After crushing and pressing the residue consists of a mixture of skin, flesh, crushed stones, kernels, water and some oil. For details see the work of Warnock (2007). It can be considered as having a compact fibre structure.
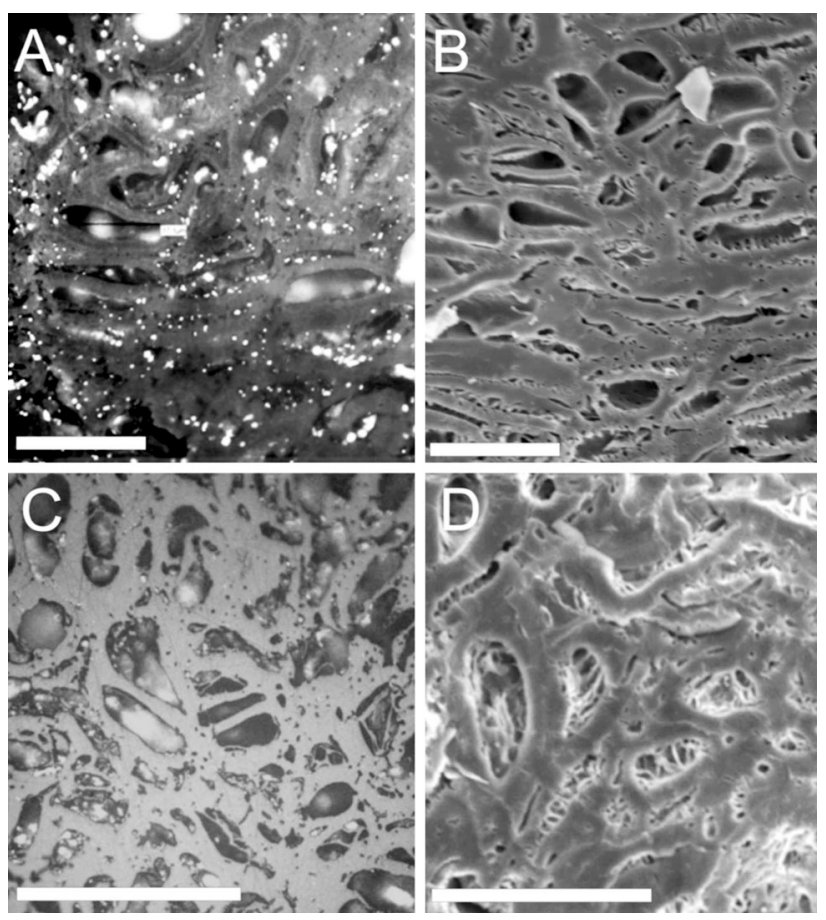

Fig. 5 Comparison of the olive stone in cross section. Charred and embedded in resin, polished and viewed under reflected light microscopy: a charred at $310{ }^{\circ} \mathrm{C}$ and $\mathbf{c}$ at $400{ }^{\circ} \mathrm{C}$. Charred and after that manually crushed and viewed under SEM: $\mathbf{b}$ at $320^{\circ} \mathrm{C}$ and $\mathbf{d}$ at $420{ }^{\circ} \mathrm{C}$. Scale bar $40 \mu \mathrm{m}$ 
$\mathbf{a}$
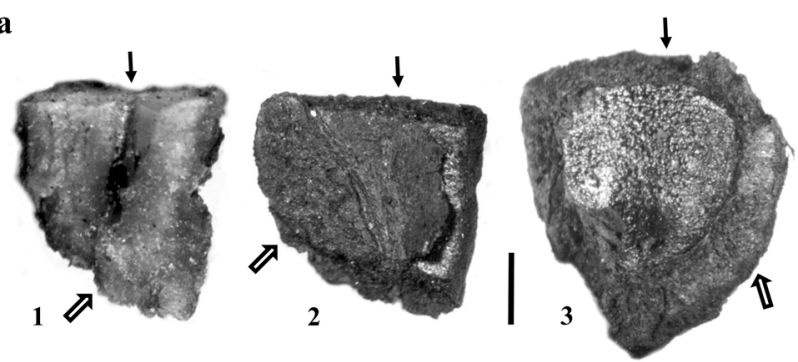

b

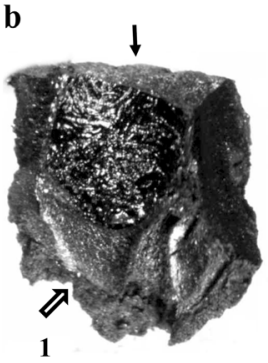

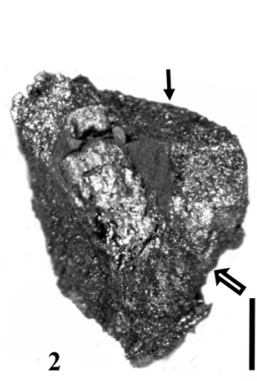

2

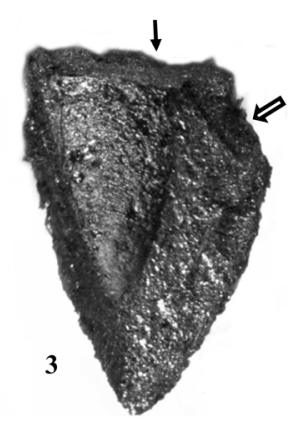

Fig. 6 Modern olive stone fragments: a (1) not charred, (2) fragmented and after that heated at $310{ }^{\circ} \mathrm{C}$ and (3) fragmented and after that charred at $370{ }^{\circ} \mathrm{C}$; b charred at the given temperatures and after that fragmented: (1) $310^{\circ} \mathrm{C}$, (2) $370{ }^{\circ} \mathrm{C}$, (3) $400{ }^{\circ} \mathrm{C}$. Arrows indicating the cross section breakage surface, filled arrows examples of sharp edges and open arrows examples of round edges. Scale bar $1 \mathrm{~mm}$

\section{Charring and ashing}

Charring OPR at 340 and $450{ }^{\circ} \mathrm{C}$ for 60 min gave a mass loss of 63.8 and $79.8 \mathrm{wt} \%$, respectively. After ashing at $450{ }^{\circ} \mathrm{C}$ for $60 \mathrm{~min}$ the mass loss for samples in the 3 crucibles was 92.13, 92.71 and $93.41 \mathrm{wt} \%$, respectively. The elemental composition of the ash (Table 4) is characterized by a high content of $\mathrm{K}\left(\mathrm{K}_{2} \mathrm{O}=38 \mathrm{wt} \%\right)$. The phytolith study showed some characteristic morphotypes in ash from OPR (Fig. 7a) as well as in ash from modern stones (Fig. 7b). The observed morphotypes were not counted, but in each field image using a magnification of $250 \times$ two or three morphotypes were observed. No calcium oxalate crystals were observed in the samples.

\section{Archaeological samples}

\section{Reflectance measurements}

The measured reflectance on the archaeological samples can be divided into two classes i.e. one showing a reflectance $(\% \mathrm{Ro})$ of around $0.9-1.0$ and one in the range of

1.4-1.7 (Table 3). Based on the calibration curve of the modern stones (Fig. 3) the samples from Poros, Tell Tweini and 2 samples of Akrotiri (806 and 1183) were exposed to temperatures in the order of $500{ }^{\circ} \mathrm{C}$, while the other four samples from Akrotiri to around $390{ }^{\circ} \mathrm{C}$.

\section{Morphology}

The samples from Poros still show preservation of cell walls in cross section, but the cells are rather unevenly distributed (Fig. 8). Cell walls have a thickness of the order of $2-3 \mu \mathrm{m}$. In Fig. $8 \mathrm{~d}$ a tendency is observed as if the material of the cell walls has merged and no cell structure is present anymore. The samples from Akrotiri shown in Fig. 9a, b, e, f have cells that are rather evenly distributed with a cell wall thickness of around 3-4 $\mu \mathrm{m}$. In samples represented in Fig. 9c, d more material is visible without cell structure compared to the other 4 samples. In general in these two samples the cell walls have a thickness of the order of 2-3 $\mu \mathrm{m}$. The samples shown from Tell Tweini have an uneven distribution of the cells and also areas where cell structure was lost. This is especially the case in Fig. 10c and no wall thickness can be measured here. Cell walls in Fig. 10a, b are about 2-3 $\mu$ m thick. The feature whereby cell structures are no longer visible and are observed as an almost homogeneous "white" surface, needs special attention. This is observed in samples from the three discussed archaeological sites (Fig. 11).

\section{Breakage surfaces of archaeological olive stone fragments}

Looking at Fig. 12a and b, not many differences are noticeable regarding the edges of the different samples. By changing the angle of illumination during observation, the sharpness of an edge could also vary significantly. Thus the determination of whether an olive stone has round or sharp edges seems rather subjective and strongly dependent on the section being examined.

\section{Discussion}

Charred organic material and inorganic ash, being the only remains of a particular fuel type that has been used for a fire to generate heat, are often present in the archaeological record. Both remains could be used to study why a particular society has selected that particular fuel to make its fires. In this study the use as fuel of OPRs in three
Table 4 Chemical composition of the modern olive residue ash in $\mathrm{wt} \%$

\begin{tabular}{lllllllll}
\hline Material & $\mathrm{SiO}_{2}$ & $\mathrm{CaO}$ & $\mathrm{K}_{2} \mathrm{O}$ & $\mathrm{P}_{2} \mathrm{O}_{5}$ & $\mathrm{Al}_{2} \mathrm{O}_{3}$ & $\mathrm{Fe}_{2} \mathrm{O}_{3}$ & $\mathrm{TiO}_{2}$ & $\mathrm{MgO}$ \\
\hline Olive residue & 10 & 36 & 38 & 11 & 0.71 & 1.18 & 0.02 & - \\
\hline
\end{tabular}


a

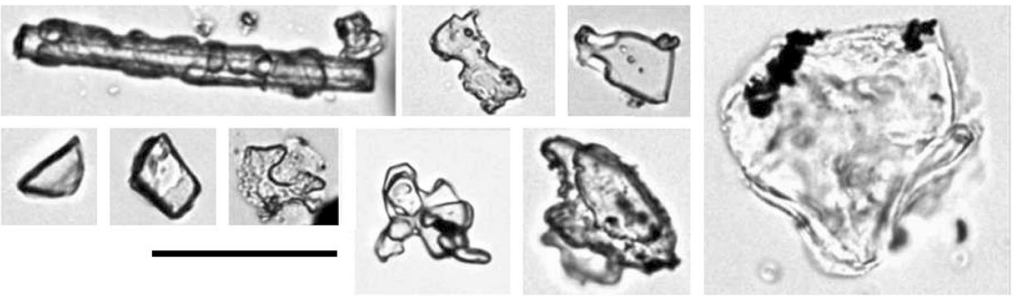

b

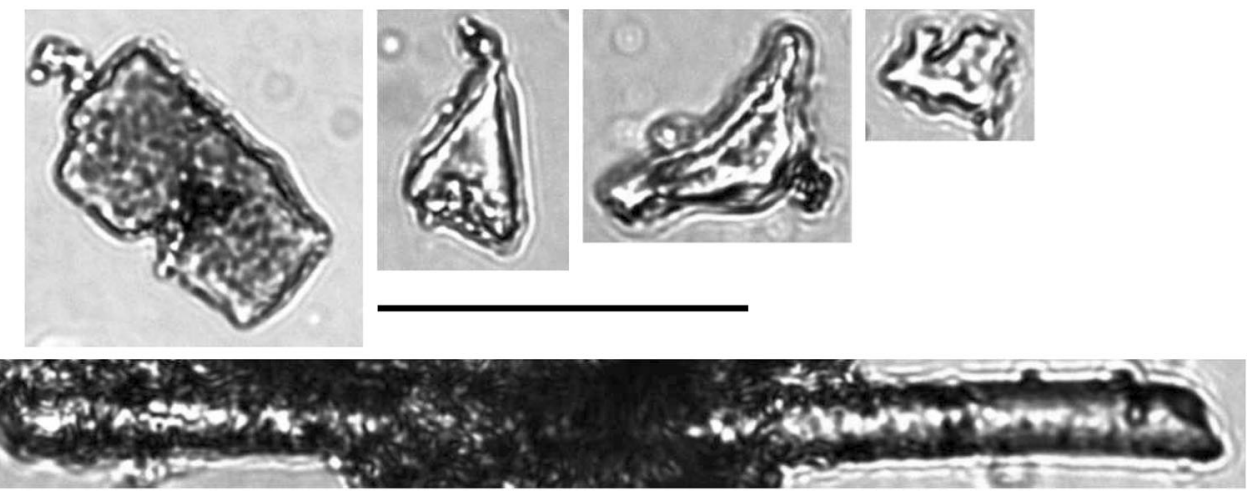

Fig. 7 Phytolith morphotypes observed in ash from a modern olive pressing residue and $\mathbf{b}$ modern olive stones. Scale bars in figure $50 \mu \mathrm{m}$
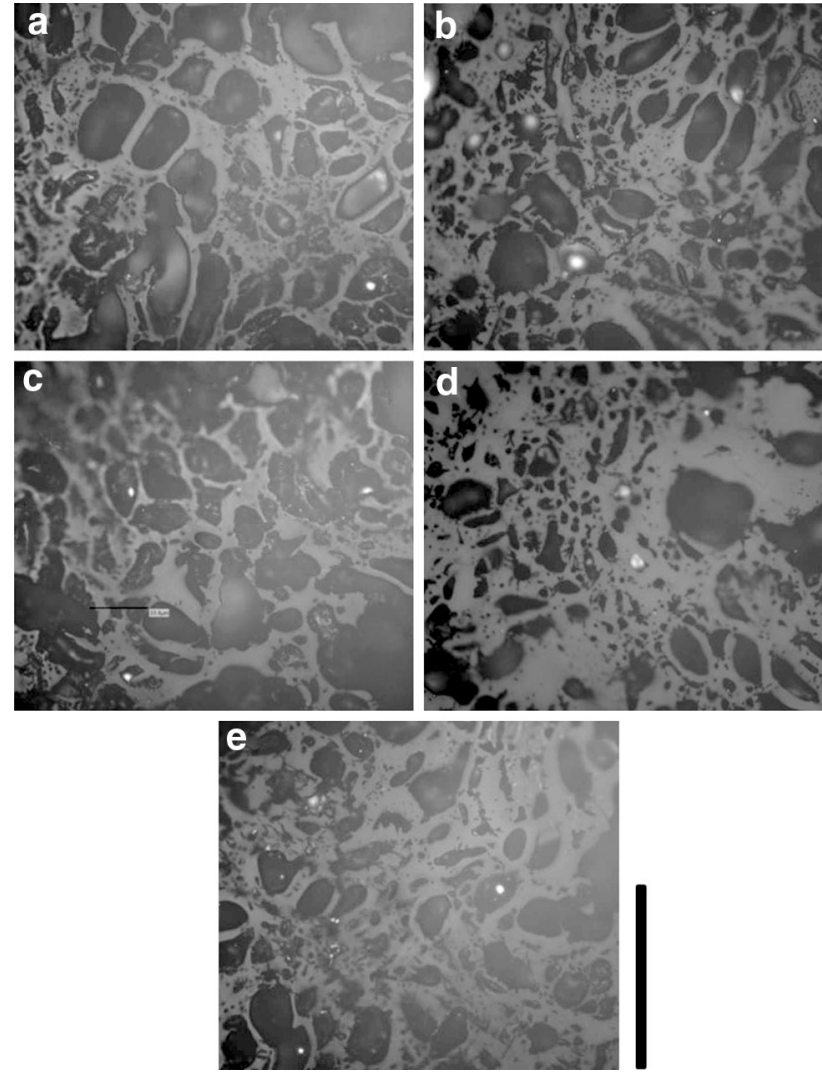

Fig. 8 Poros. Micrographs under reflected light of fragmented olive stone char structures of sample a WF112R, b WF115, c WF118R, d WF114R and e WF273R. Scale bar $100 \mu \mathrm{m}$
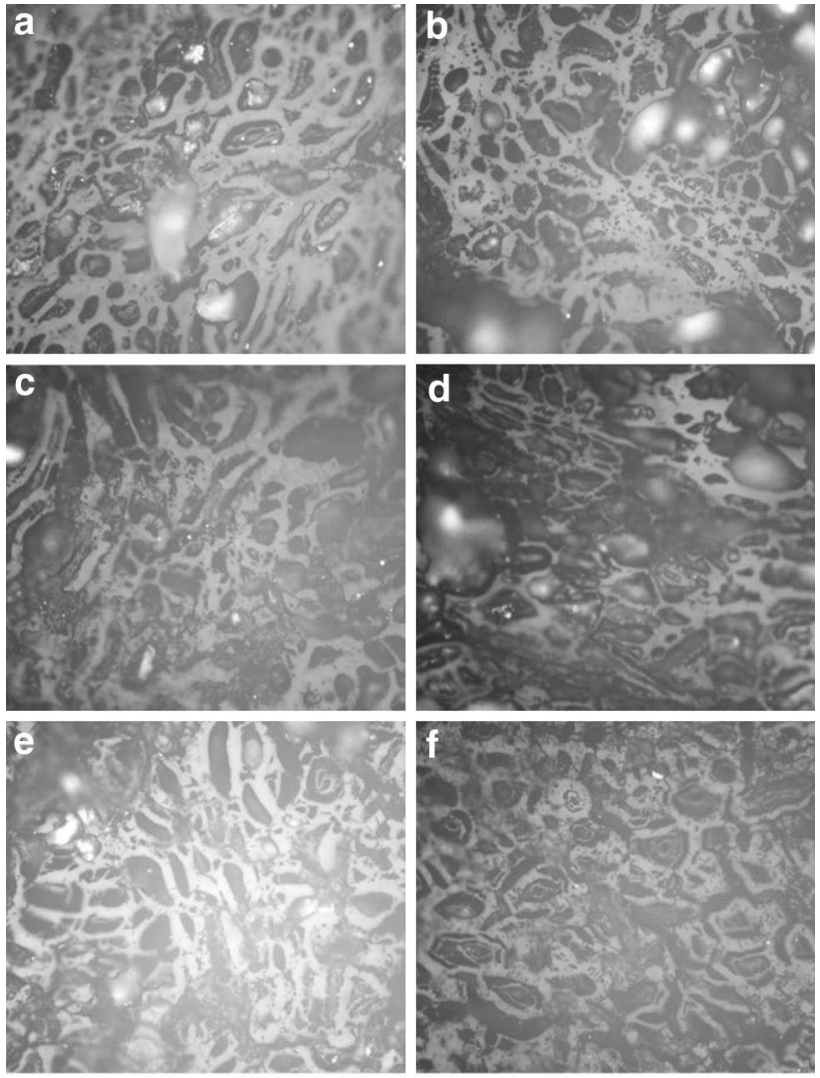

Fig. 9 Akrotiri. Micrograph under reflected light of fragmented olive stone char structures of sample a 178, b 667, c 806, d 1,183, e 580 and $\mathbf{f}$ 745. Scale bar $100 \mu \mathrm{m}$ 

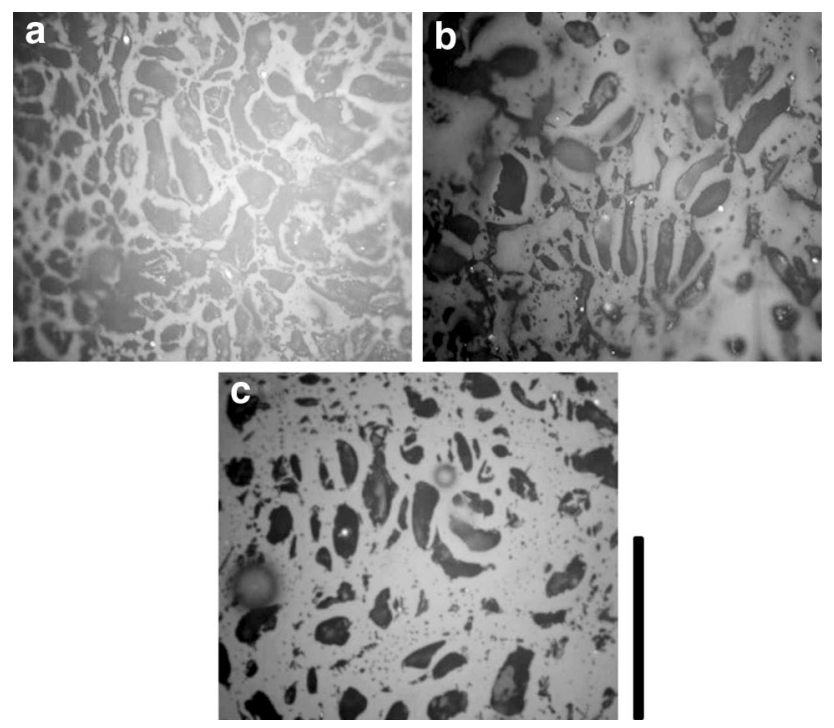

Fig. 10 Tell Tweini. Micrograph under reflected light of fragmented olive stone char structures of sample a 960-1 and b 185-3. Scale bar $100 \mu \mathrm{m}$
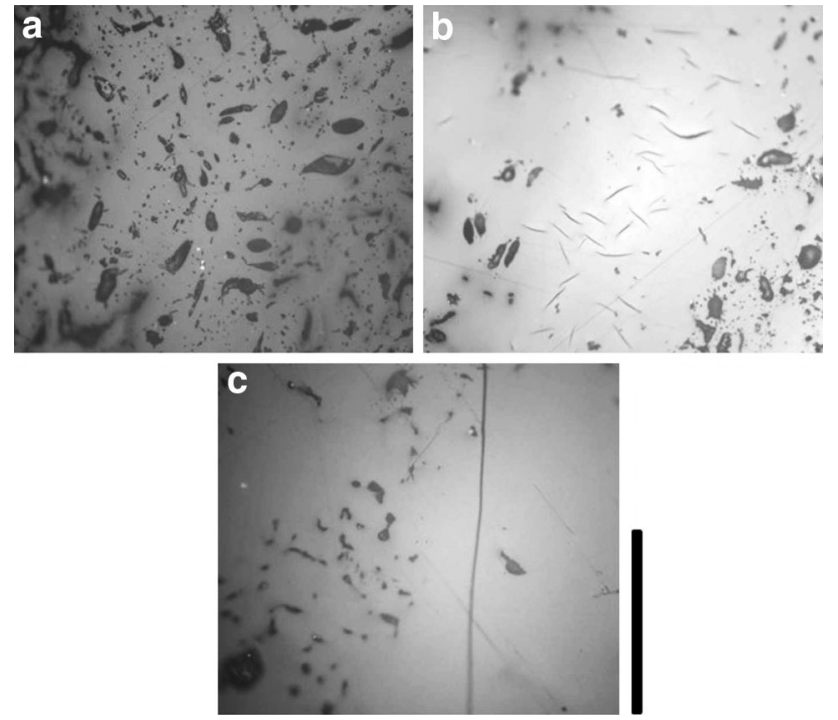

Fig. 11 Micrographs under reflected light of fragmented olive stone char structures of sample a Poros WF273R, b Akrotiri 1,183 and c Tell Tweini 185. Showing structures without the characteristic cells. Scale bar $100 \mu \mathrm{m}$

archaeological sites was investigated and compared with the properties of a heated modern OPR. The heating conditions to which charred remains were exposed in the past, breakage edges of the charred fragmented stones and ash properties were studied. In addition to the normal botanical procedures this may be of great help to reveal facts about ancient societies that might otherwise be lost. It is noted that the observations in the current study are restricted to the use of fuel in fire structures made and used by ancient societies.

\section{Fuel characteristics}

The main constituent of OPR is biological matter, which on being heated, and after reaching a temperature of about $280-300{ }^{\circ} \mathrm{C}$, converts into a new carbon rich product. This latter mainly consists of aromatic compounds and as a result the carbon component increases from 50 to $70 \mathrm{wt} \%$ (for details see Braadbaart et al. 2012). This particular process occurs independently of the presence or absence of air. The chemical conversion is accompanied by the release of a high number of volatiles, which explains the strong mass loss of organic material at this temperature range. When the hot carbon rich material has access to air, and as a result of the presence of oxygen in the air, the carbon will be oxidised into carbon dioxide $\left(\mathrm{CO}_{2}\right)$, a reaction that will release much energy in the form of heat. In this way a heat source is formed, which could be a smouldering, a flaming or a glowing fire (Rein 2009). As shown OPR has additional properties that makes it an excellent and efficient fuel i.e. the presence of potassium, some residual oil, a low ash content and its compact fibre structure (Table 2). The presence of oil is asserted by the mass loss of modern OPR at $450{ }^{\circ} \mathrm{C}$ of $79.8 \mathrm{wt} \%$ compared to a mass loss of about $72 \mathrm{wt} \%$ for modern stones. This difference can be explained by the presence of oil in the residue as oil evaporates when the temperature is higher than $340{ }^{\circ} \mathrm{C}$ (Braadbaart et al. 2007). The characteristic compact fibre structure of OPR makes it an excellent fuel for preparing food as it burns with a slow, long-lasting flame. COPR, the charred version of OPR, with its high HHV of around $30 \mathrm{MJ} / \mathrm{kg}^{-1}$, its large internal surface and therefore high reactivity, is an even more efficient fuel. Moreover, it provides a fire using less fuel compared to OPR under identical heating conditions, is easier to transport since the weight has decreased substantially (mass loss of about $70 \mathrm{wt} \%$ ) and burns almost free of smoke.

\section{Charred fragmented olive stones}

\section{Heating conditions}

In heating modern stones, above a temperature of around $300{ }^{\circ} \mathrm{C}$ the strong mass loss results in a decrease of the cell wall material (Fig. 2 and insert and Fig. 4). The processes explaining the mass losses of organic material as a result of heating are extensively discussed in many papers and for more information the reader is referred to these (Shahfizadeh and Bradbury 1979; Boon et al. 1994; Braadbaart 2004). Hence, the finding of small fragments of charred olive stones from the various investigated sites could be related to mass reduction due to heating of the stones. When observing the charred fragments of the archaeological stones from the three sites a considerable shrinkage of 
the cell walls is observed in comparison to the thickness of the walls in stones that have not been heated (Figs. 8, 9, 10). The thickness of the observed cell walls is in the range of 3-4 $\mu \mathrm{m}$ and corresponding to a temperature of around $450{ }^{\circ} \mathrm{C}$ (Fig. 2 insert). These observations suggest that the archaeological olive stone fragments have been heated at relatively high temperatures in the range of $400-500{ }^{\circ} \mathrm{C}$ and thus higher than temperatures necessary to prepare food (Braadbaart pers. observations). The results of the reflectance measurements, showing temperatures of around $500{ }^{\circ} \mathrm{C}$ for the majority of the archaeological samples (Table 3), correspond to these observations. To make a good quality (hard and no dust) of charcoal, and thus to produce COPR, a temperature in the range of $450-500{ }^{\circ} \mathrm{C}$ with little or no air, is considered necessary (Antal and Grönli 2003). Another striking feature of the charred archaeological olive stones are the areas in which the characteristic cell structures are not present anymore (Fig. 11). It is suggested that these areas, often called "glassy or vitreous" matter, are attributable to the heating conditions during the production of a material like COPR and charcoal. Although, the exact mechanism of how these features are formed is not yet clear, it seems reasonable to assume that one or more of the constituent compounds of the cell walls have become viscous and as a result have lost their cell structure. A similar phenomenon, the presence of protrusions on charred wheat grains, where also no cell structures were observed, could also be explained by this process whereby the organic constituents have first to become viscous in order to be able to flow out of the grain (Braadbaart 2008). Identical phenomena were also observed in experiments with the production of charred organic material at around $500{ }^{\circ} \mathrm{C}$ in the laboratory (unpublished data). The reflectance measured on all these areas shows a temperature of around $500{ }^{\circ} \mathrm{C}$. It is noted that the reflectance values measured on the charred remains of a COPR fuel, even when later used as a fuel for the preparation of food at lower temperatures, will still show the higher reflectance values related to $500{ }^{\circ} \mathrm{C}$, since only the highest temperature ever reached in charred material is measured (Braadbaart et al. 2012). Based on these observations it is tentatively concluded that the recovered fragments of charred fragmented olive stones from Poros and Tell Tweini derive from a COPR fuel. For the samples from Akrotiri (Table 3) this seems less clear since the temperature for four out of six samples was in the order of $390{ }^{\circ} \mathrm{C}$, but they still show the characteristic morphology without cell structures. This temperature, high enough to produce a char, but of lower quality, indicates that here also COPR could have been used as fuel. It seems rather logical that the production of COPR was performed next to the olive-oil producing area and not near to the area where the fuel was needed. COPR is much lighter than dried OPR and could be relatively easily transported to sites where not enough other fuel types were available. This may have been especially attractive in cases the fuel had to be transported by sea. For example, on the island of Poros charcoal is found showing the same temperatures and morphological features while it was discovered that during the period investigated no wood was available on the island (Penttinen and Wells 2009). So it is assumed that fuel had to come from the mainland. According to the palynological evidence from Tell Tweini (Kaniewski et al. 2009) the olives growing around the site before the Iron Age belonged mainly to wild stands and could have covered a wider area of collection. Hints of this are also provided by the stable isotope analyses of olive stones from the Bronze Age at Tell Tweini, suggesting an origin of the olives from a wider region than the immediate proximity of the site. The low concentration of wood charcoals in the Bronze Age layers (Marinova et al. 2012) on the other hand also suggests the need of alternative fuel so most probably OPR were brought to the site to use as a heat source.

The observations of the cross sections of the olive stones under high magnification, using the Leitz DMLA microscope, could be diagnostic for the heating conditions of the heat source such as temperature and subsequently for considering whether or not they were charred prior to use as fuel. Using these features makes it necessary to perform reflectance measurements and since most archaeologists do not have the special equipment necessary, they use SEM instead. The results show that both methods show the morphology and can be used (Fig. 5). On the other hand by using SEM the temperature cannot be measured, although the thickness of the cell walls could give more related information as well as characteristics of the morphology such as the presence or absence of cell structures.

\section{Breakage surfaces}

In order to achieve uniformity in the observations it was decided to consider the breakage surface in cross section of the olive stone, as this can be easily and unambiguously reproduced. This surface has the best chance to be diagnostic in observing the anatomy of the breakage and can also be compared with the anatomical features visible in thin sections (Fig. 5).

In the archaeobotanical literature, charred olive stone fragments with weathered or rounded fractures are considered to indicate that fragmentation preceded charring and thus was not the result of flotation or post-depositional damage, but of crushing and pressing the olives and thus the stones during oil extraction (Neef 1990; Smith 1998; Sarpaki in press; Simchoni and Kislev 2006; Margaritis and Jones 2008a, b; Salavert 2008; Marinova et al. 2011; Rowan 2015). However, the experimental evidence shown 
in those publications is not always clear and does not show measurable rounding and smoothing of the edges due to fragmentation prior to burial. The results of the current study show that the fragments of stones charred after crushing the olives have rather sharp edges in cross section (Fig. 6a) just as in the case when charred stones are crushed before heating (Fig. 6b). After deposition in the soil (archaeological record) charred remains do not behave as inert material, but can be affected by the natural processes that may occur in their environment (diagenesis). For example, under alkaline conditions $(\mathrm{pH}>7)$, such as in ash usually accompanying the heated plant remains, strong fragmentation will occur (Braadbaart et al. 2009), and as a result edges of stones may be transformed. So depending on the conditions in the soil, serious changes in the form of the edges can occur due to post-depositional processes. The stone fragments from Poros, Akrotiri and Tell Tweini show both sharp and round edges (Fig. 12). At these sites, the archaeobotanical samples have been exposed to flotation and the stone fragments could be broken again resulting in sharp edges. However, numerous finds of olive stone fragments from archaeological sites (for a most recent discussion see Kaniewski et al. 2012) could be considered as remains from oil crushing and pressing.

\section{Ash properties}

The identification of fuels by their ash is still far from being a routine practice in archaeology, as is shown amongst others by the investigation of the three studied sites. This could be mainly due to lack of a standard methodology, although recent studies have paid much attention to this issue (Canti 2003; Portillo and Albert 2011; Lancelotti and Madella 2012; Braadbaart et al. 2012; Shahack-Gross and Ayalon 2013; Gur-Arieh et al. 2014 and the references cited therein). The study of ash (and char) should be part of an archaeological investigation in order to obtain a fuller picture of fuel use. Although no ash was collected and investigated in the three studied sites the results from the ash obtained from the modern OPR gave reason to pay attention to this issue. The two main analyses for characterizing ash are the elemental composition and the presence of elements like silica phytoliths, calcium oxalate crystals and others. The modern OPR has a K content of $38 \mathrm{wt} \%$ (Table 4), which is rather high in comparison to other fuels like wood, dung and peat (between 6 and $1.5 \mathrm{wt} \%$ ) (Braadbaart et al. 2012). It is noted that elements like $\mathrm{K}$ are prone to post-depositional processes, since under certain circumstances they are easily dissolved. The high $\mathrm{Ca}-\mathrm{SI}$ ratio of a dung fuel for example makes it possible to distinguish it from the low $\mathrm{Ca}-\mathrm{Si}$ ratio of OPR (Canti 2003). Thus the analyses of the chemical composition of ash from OPR offer possibilities for distinguishing it from other fuel types. Another question worth further exploration is the presence of phytoliths and/or Ca-oxalate crystals in ash from OPR and/or modern olive stones. In olive fruits the presence of phytoliths seems to be rather limited (Tsartsidou et al. 2007), although in the ash of the current modern OPR (Fig. 7a) and modern olive stones (Fig. 7b) it is interesting that several morphotypes of phytoliths were observed but not further determined. Ca-oxalate crystals were not recognized. Based on these results it is recommended that further investigation should be made and much more attention be paid to exploring the potential for recognising diagnostic phytoliths in this type of ash.

\section{Conclusions}

Based on the above discussions it is evident that char and ash can provide useful information pertaining to the fuel used. The ubiquitous presence of charred fragments of olive stones recovered from fire structures in archaeological excavations in the Mediterranean region makes it an important material for this kind of research (see the investigated sites). It is assumed that the charred fragments are the residues of olive oil processing, which were used as fuel for fires to generate heat.

This study shows that the OPRs are excellent and efficient fuels that can be used either directly after drying or after being upgraded by further heating as a charred variety. The latter has a higher heating potential and thus needs considerably less fuel to obtain an identical type of fire, in addition to being much lighter in weight and thus easier to transport to areas where no other fuel sources are present. Another advantage is that the fire burns almost smoke free. The methods developed make it possible to distinguish between both types of fuel allowing the gathering of important information on why an ancient society used a particular type of fuel. For this purpose the measurement of the amount of reflected light from polished samples is usually used, whereas in this study the results have been compared to observations under SEM. It is shown that the wall thickness of the cell material could be used for the same purpose, this method being more easily available within the methods normally used by archaeologists.

The study of the properties of ash formed after combustion of the OPR and COPR could be an important method for investigating which types of fuel have been used. The chemical composition and the identification of phytoliths and other biogenic crystals would be the features to be explored further.

The current study has shown that the form of the edges of fragments of charred olive stones is not a reliable criterion for recognising the methods by which olive oil production was performed. The shape of the edges is 
a
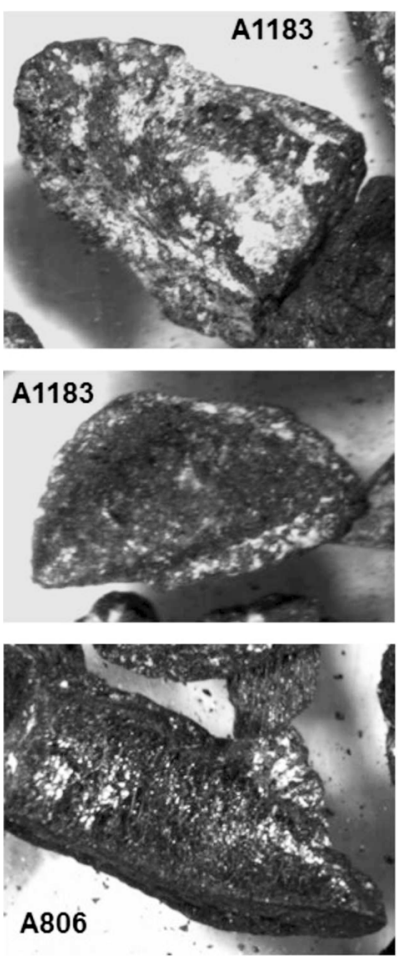

b
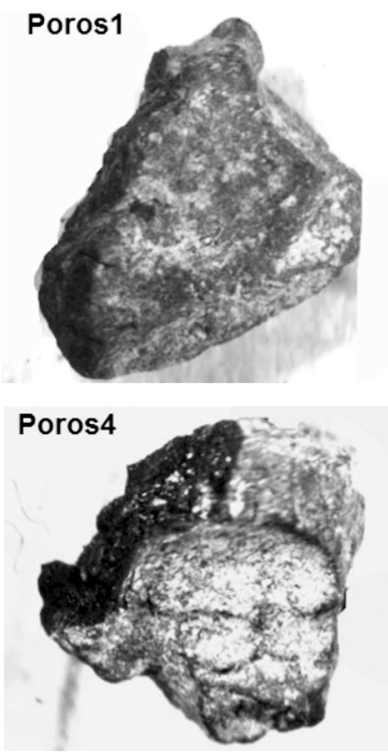

Poros1

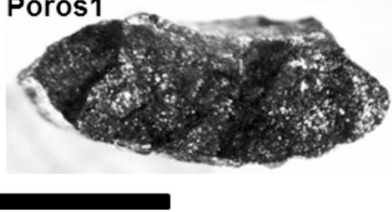

A580

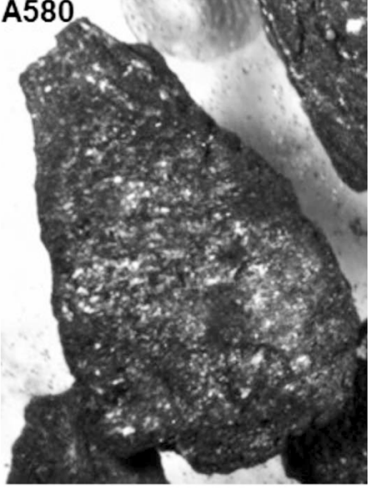

Poros1

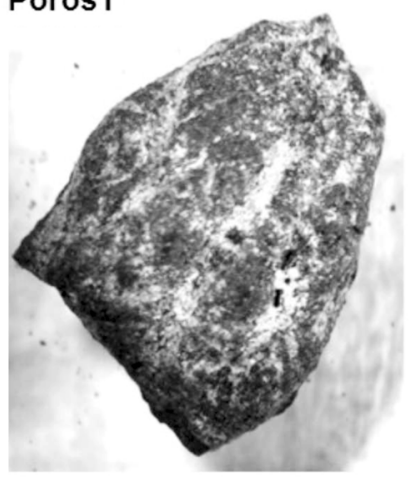

A923

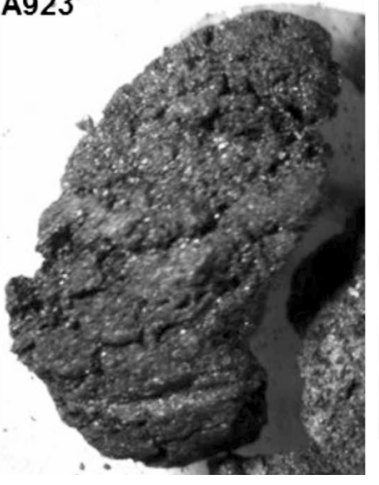

Fig. 12 Fragments of charred olive stones after water flotation from Akrotiri and Poros; a showing sharp edges, b showing round edges. Scale bars $5 \mathrm{~mm}$

affected by post-depositional processes, as well as by the retrieval of the charred plant remains from the sediments.

Char as well as ash are extremely vulnerable to excavation processes (Matthews 2010). Chars from olive tissues are friable and easily destroyed, while the small ash grains are easily lost. Special care needs to be taken to circumvent these problems. Sieving and flotation should be avoided as much as possible when studying ancient fuel remains. It is suggested that sub-sampling by hand of collected bulk sediment should accompany the normal excavation activities, which involve flotation on a large scale.

It is noted that charred material is not inert. Under circumstances where the $\mathrm{pH}$ is higher than around 8 , strong fragmentation may occur and only small fragments are left. (Braadbaart et al. 2009).

It is suggested that apart from botanical identification, an important part of an archaeological investigation are the methods suggested in this study for analysing the remains of fuels. These methods could not only add much valuable information related to how ancient societies selected these fuels for their heat sources, but also on the relative level of generation, control and application of heat (pyrotechnology).

Acknowledgments The authors would like to thank Peter Warnock from Columbia Mo, USA for providing the modern olive oil pressing residue and the fruitful discussions. Technical assistance with the reflectance measurements by Harry Veld of Deltares (Utrecht, the Netherlands) is greatly acknowledged. We thank Arto Penttinen from the Swedish Institute of Archaeology in Athens (Greece), for hospitality and allowing sampling on Kalaureia, and $\mathrm{Ch}$. Doumas for allowing us to work and take samples at Akrotiri on Thera (Greece). The comments of Corrie Bakels (Faculty of Archaeology, Leiden University, the Netherlands) and two anonymous reviewers, which led to an improvement of this manuscript, are greatly appreciated.

Open Access This article is distributed under the terms of the Creative Commons Attribution 4.0 International License (http://crea tivecommons.org/licenses/by/4.0/), which permits unrestricted use, distribution, and reproduction in any medium, provided you give appropriate credit to the original author(s) and the source, provide a link to the Creative Commons license, and indicate if changes were made.

\section{References}

Antal JA, Grönli M (2003) The art, science, and technology of charcoal production. Ind Eng Chem Res 42:1,619-1,640

Bakels CC (1984) Carbonized seeds from Northern France. Analecta Praehist Leidensia 17:1-25

Boon JJ, Pastorova I, Botto RE, Arisz PW (1994) Structural studies on cellulose pyrolysis and cellulose chars by PYMS, PYGCMS, FTIR, NMR and by wet chemical techniques. Biomass Bioenergy $7($ s1-6):25-32 
Braadbaart F (2004) Carbonization of peas and wheat - a window into the past: a laboratory study. Diss., Universiteit Leiden, Leiden. http:// www.amolf.nl/publications/theses/braadbaart/braadbaart.htlm

Braadbaart F (2008) Carbonisation and morphological changes in modern dehusked and husked Triticum dicoccum and Triticum aestivum grains. Veget Hist Archaeobot 17:155-166

Braadbaart F, Poole I (2008) Morphological, chemical and physical changes during charcoalification of wood and its relevance to archaeological contexts. J Archaeol Sci 35:2,434-2,445

Braadbaart F, Wright PJ, van der Horst J, Boon JJ (2007) A laboratory simulation of the carbonization of sunflower achenes and seeds. J Anal Appl Pyrolysis 78:316-327

Braadbaart F, Poole I, van Brussel AA (2009) Preservation potential of charcoal in alkaline environments: an experimental approach and implications for the archaeological record. J Archaeol Sci 36:1,672-1,679

Braadbaart F, Poole I, Huisman DJ, van Os B (2012) Fuel, fire and heat: an experimental approach to highlight the potential of studying ash and char remains from archaeological contexts. J Archaeol Sci 39:836-847

Bretschneider J, van Lerberghe K (eds) (2008) In search of Gibala: an archaeological and historical study based on eight seasons of excavations at Tell Tweini (1999-2007) in the A and C fields.(Aula Orientalis-Supplementa 24) Editorial AUSA, Barcelona

Canti MG (2003) Aspects of the chemical and microscopic characteristics of plant ashes found in archaeological soils. Catena 54:339-361

Demirbaş A, Ilten N (2004) Fuel analyses and thermochemical processing of olive residues. Energy Sources 26:8,731-8,738

Di Blasi C (2009) Combustion and gasification rates of lignocellulosic chars. Prog Energy Combust Sci 35:121-140

Doumas CG (1983) Thera, Pompeii of the ancient Aegean: excavations at Akrotiri 1967-1979. Thames and Hudson, New York

Emmons HW, Atreya A (1982) The science of wood combustion. Proc Indian Acad Sci (Eng Sci) 4:259-268

Franceschi VR, Nakata PA (2005) Calcium oxalate in plants: formation and function. Ann Rev Plant Biol 56:41-71

Goudsblom J (1992) Fire and civilization. Allen Lane, London

Grioui N, Halouani K, Zoulalian AA, Halouani Maderas F (2007) Experimental study of thermal effect on olive wood porous structure during carbonization. Cienc y Tecnol 9:15-28

Gur-Arieh S, Shahack-Gross R, Maeir AM, Lehmann G, Hitchcock LA, Boaretto E (2014) The taphonomy and preservation of wood and dung ashes found in archaeological cooking installations: case studies from Iron Age Israel. J Archaeol Sci 46:50-67

Jenkins BM, Baxter LL, Miles TR Jr (1998) Combustion properties of biomass. Fuel Process Technol 54:17-46

Kaniewski D, Paulisen E, van Campo E, Bakker J, van Lehrberge K, Waelkens M (2009) Wild or cultivated Olea europaea L. in the eastern Mediterranean during the middle-late Holocene? A pollen-numerical approach. Holocene 19:1,039-1,047

Kaniewski D, van Campo E, Boiy T, Terral J-F, Khadari B, Besnard G (2012) Primary domestication and early uses of the emblematic olive tree: palaeobotanical, historical and molecular evidence from the middle east. Biol Rev 87:885-899

Lancelotti C, Madella M (2012) The 'invisible' product: developing markers for identifying dung in archaeological contexts. J Archaeol Sci 39:953-963

Madella M, Alexander A, Ball T (2005) International Code for phytolith nomenclature 1.0. Ann Bot 96:253-260

Margaritis E, Jones MK (2008a) Crop processing of Olea europaea L.: an experimental approach for the interpretation of archaeobotanical olive remains. Veget Hist Archaeobot 17:381-392

Margaritis E, Jones MK (2008b) Olive oil production in Hellenistic Greece: the interpretation of charred olive remains from the site of Tria Platania, Macedonia, Greece (fourth-second century B.C.). Veget Hist Archaeobot 17:393-401

Marinova E, van der Valk JMA, Valamoti SM, Bretschneider J (2011) An experimental approach for tracing olive processing residues in the archaeobotanical record, with preliminary examples from Tell Tweini, Syria. Veget Hist Archaeobot 20:471-478

Marinova E, Linseele V, Vandorpe P, van der Valk J (2012) Middle Bronze Age ritual, subsistence and environment at Tell Tweiniinferred from bioarchaeological evidence. In: Boiy $\mathrm{T}$, Bretschneider J, Goddeeris A, Hameeuw H, Jans G, Tavernier $\mathrm{J}$ (eds) The ancient near east, a life! orientalia lovaniensia analecta 220. Peeters Publishers, Leuven, pp 345-364

Matthews W (2010) Geoarchaeology and taphonomy of plant remains and micro-archaeological residues in early urban environments in the ancient near east. Quat Int 214:98-113

Miranda T, Esteban A, Rojas S, Montero I, Ruiz A (2008) Combustion analysis of different olive residues. Int J Mol Sci 9:512-525

Mumford L (1963) Technics and civilization. Harcourt Brace Jovanovich, New York

Neef R (1990) Introduction, development and environmental implications of olive culture: the evidence from Jordan. In: Bottema S, Entjes-Nieborg G, Van Zeist W (eds) Man's role in the shaping of the eastern mediterranean landscape. Balkema, Rotterdam, pp 95-306

Niaounakis M, Halvadakis CP (2006) Olive-mill waste management: literature review and patent survey. Typothito Publications, Athens

Pearsall DB (2000) Paleoethnobotany: a handbook of procedures, 2nd edn. Academic Press, San Diego

Penttinen A, Wells B (2009) Report on the excavations in the years 2007 and 2008 southeast of the Temple of Poseidon at Kalaureia. Opuscula 2:89-133

Piperno DR (2006) Phytoliths: a comprehensive guide for archaeologists and paleoecologists. AltaMira Press, Lanham

Portillo M, Albert RM (2011) Husbandry practices and livestock dung at the Numidian site of Althiburos (el Médéina, Kef Governorate, northern Tunisia): the phytolith and spherulite evidence. J Archaeol Sci 38:3,224-3,233

Rein G (2009) Smouldering combustion phenomena in science and technology. Int Rev Chem Eng 1:3-18

Rowan E (2015) Olive oil pressing waste as a fuel source in antiquity. Am J Archaeol 119:465-482

Salavert A (2008) Olive cultivation and oil production in Palestine during the early Bronze Age (3500-2000 B.c.): the case of Tel Yarmouth, Israel. Veget Hist Archaeobot 17 (Suppl 1):53-61

Sarpaki A (in press) The visibility of the olive at Akrotiri, Thera and its importance for the Bronze Age society. In: Doumas C (ed) Forty years of excavations at Akrotiri, Thera. Archaeological Society of Greece, Athens

Sarpaki A, Asouti E (2008) A glimpse through a kitchen key-hole at Late Bronze Age Akrotiri: the organic remains. In: Brodie N, Doole J, Gavalas G, Renfrew C (eds) Horizon: a colloquium on the prehistory of the CYCLADES. McDonalds Institute Monographs, Cambridge, pp 370-376

Shahack-Gross R, Ayalon A (2013) Stable carbon and oxygen isotopic compositions of wood ash: an experimental study with archaeological implications. J Archaeol Sci 40:570-578

Shahfizadeh F, Bradbury AGW (1979) Thermal degradation of cellulose in air and nitrogen at low temperatures. J Appl Polym Sci 23:1,431-1,442

Simchoni O, Kislev ME (2006) Charred by-products of olive-oil production in the iron age. In: Mazar A, Amitai-Preiss N (eds) Excavations at Tel Beth-Shean 1989-1996. Beth-Shean Valley Archaeological Project publication 1. Institute of Archaeology, the Hebrew University of Jerusalem, Jerusalem, pp 679-685 
Smith W (1998) Fuel for Thought: archaeobotanical evidence for the use of alternatives to wood fuel in Late Antique North Africa. J Mediterr Archaeol 11:191-205

Tortosa Masiá AA, Buhre BJP, Gupta RP (2007) Characterising ash of biomass and waste. Fuel Process Technol 88:1,071-1,081

Tsartsidou G, Lev-Yadun S, Albert R-M, Miller-Rosen A, Efstratiou N, Weiner S (2007) The phytolith archaeological record: strengths and weaknesses evaluated based on a quantitative modern reference collection from Greece. J Archaeol Sci 34:1,262-1,275

Tyree EL (1994) Phytolith analysis of olive oil and wine sediments for possible identification in archaeology. Can J Bot 72:499-504

Tyree EL, Stefanoudaki E (1997) There is more than one way to crush an olive: does the pit affect flavor? In: Gillis C, Risberg C, Sjöberg B (eds) Trade and production in premonetary Greece. Production and the Craftsman Proceedings of the 4th and 5th International Workshops, Athens 1994 and 1995. Paul Äströms forlag, Jonsered
Vamvuka D (2008) Comparative fixed/fluidized bed experiments for the thermal behaviour and environmental impact of olive kernel ash. Renew Energy 34:158-164

Varol M (2006) Combustion and co-combustion of olive-cake and coal in a fluidized bed. Thesis Middle East Technical University, Ankara

Vassilev SV, Baxter D, Andersen LK, Vassileva CG (2010) An overview of the chemical composition of biomass. Fuel 89:913-933

Vaughan JG (1970) The structure and utilization of oil seeds. Chapman and Hall Ltd, London

Warnock P (2007) Identification of ancient olive oil processing methods based on the olive remains. BAR International Series $\mathrm{S}$ 1635. Archaeopress, Oxford

Winton AL, Winton KB (1932) Fruit of the olive family. The structure and composition of foods. Cereals, starch, oil seeds, nuts, oils, forage plants, vol 1. Wiley, New York, pp 587-597 